\title{
THE FLORA OF THE FOX HILLS SANDSTONE.
}

\author{
By F. H. Knowlton.
}

\section{INTRODUCTION.}

A knowledge of the land plants of the Rocky Mountain region in Fox Hills time has long been desired, because the Fox Hills sandstone lies between formations that are abundantly plant bearing. As the Fox Hills is a marine formation, it probably nowhere carries the remains of a large land flora, although, as it was evidently deposited near shore in rather shallow water, it doubtless includes some small pockets or deposits in which the remains of land plants may be discovered. Isolated specimens of such plants have been found in the formation at several localities, and the peculiar marine alga Halymenites is at many places abundant in its beds, but never before, so far as I know, have collections 'so large as those here considered been described and figured.

The type locality of the Fox Hills sandstone is near Fox Ridge, between Cheyenne and Moreau rivers, S. Dak. Its thickness at this place reaches about 325 feet and in near-by areas in North and South Dakota ranges from 25 feet or less to 450 feet. At a few places where the underlying and overlying formations occur and it should theoretically be present it may be entirely absent, as at a locality on Worthless Creek, S. Dak., reported by Calvert. ${ }^{1}$ In the Denver Basin in Colorado, according to Eldridge, ${ }^{2}$ the formation has a normal thickness of 800 to 1,000 feet, and at only one locality does its thickness fall to 500 feet. Later students of the geology of Colorado have been inclined to reduce its thickness in this region greatly, perhaps to restrict it to little more than the upper 100 feet of the beds it now includes, but according to T. W. Stanton there is

1 Calvert, W. R., Geology of the Standing Rock and Cheyenne River Indian reservations, North and South Dakota: U. S. Geol. Survey Bull. 575, p. 18, 1914.

2 Eldridge, G. H., Geology of the Denver Basin in Colorado: U. S. Geol. Survey Mon. 27, p. 71, 1896. no obvious faunal evidence for changing the established line between the Fox Hills and the underlying Pierre shale.

The material on which the following notes are based comes from the Greeley quadrangle, Colo. Part of it was obtained by T. E. Williard, of the United States Geological Survey, during the field season of 1914 , at two localities, one, affording the larger collection, on Wildeat Mound, about $2 \frac{1}{2}$ miles south of Milliken, and the other on the north side of Thompson Creek about $1 \frac{1}{4}$ miles northeast of Milliken. The matrix in which the plant remains occur is a yellowish-brown, rather coarse sandstone, and the leaves are fragmentary or so curled up that it is difficult to procure perfect specimens. The exact position of the plant-bearing beds in the local section was not determined, though according to Mr. Williard they are probably within 100 feet of the top. They are, however, undoubtadly below beds containing a typical Fox Hills fauna.

In 1915 these localities were visited by T. W. Stanton, who was able to confirm Mr. Williard's observations concerning the stratigraphic relations of the plant-bearing beds. He also obtained additional material about a quarter of a mile east of Mr. Williard's locality northeast of Milliken, but apparently in beds at nearly the same level, about 21 feet below the top of a massive sandstone in the Fox Hills and probably 100 feet below the top of the formation.

The occurrence of fossil plants in this general region in the midst of or at least below welldefined marine beds has long been known, though apparently this is the first material that has been found so well preserved as to permit adequate description. In 1873 Stevenson ${ }^{3}$ found abundant plant remains at a locality which must have been the same as or near the one that has afforded the present collec-

${ }^{3}$ Stevenson, J. J., Report on the geology of a portion of Colorado: U. S. Geog. Surveys W. 100th Mer. Rept., vol. 3, p. 406, 1875. 
tions. Concerning this locality he wrote as follows:

Following this rock [Cretaceous] down the South Platte River, we find the lower part of the section well exposed for many miles below the junction of St. Vrains Creek and the river. Here, at a horizon above that of the Platteville coals, the exposure is similar to that at Canon City. At the river level are shales, argillaceous and arenaceous, gradually passing upward into a bluish-gray, very friable sandstone, on which rests a red friable sandstone containing many thin layers which are slightly calcareous. Owing to the superior hardness of the calcareous layers this red sandstone, in weathering, assumes eccentric forms similar to those common on Monument Creek and illustrated in Dr. Hayden's reports. The harder layers are richly fossiliferous. Some of them are made up almost wholly of Halymenites major Lesquereux, others literally crowded with remains of Mollusca, and one contains many leaves of dicotyledonous plants. The shale section overlies the important coal beds at Platteville and is traceable down the river for a long distance, the dip in that direction being very slight. Near Evans and in the highest portion of the sandstone the layers containing the fucoid alternate with those containing Mollusca, and the leaf bed is underlaid and overlaid by both fucoidal and molluscan layers. Unfortunately the impressions of the leaves are not sharp, and but one specimen was preserved.

As certain of his observations made in 1873 had been called in question, Stevenson revisited the locality in 1878, and the results of this later visit were published in the following year. ${ }^{1}$ His observations were confined mainly to the area on the west side of South Platte River between St. Vrain and Thompson creeks, and for several miles up these streams. In low bluffs both north and south of Thompson Creek he noted a sandstone, which, he says,

is bright yellow and for the most part extremely friable, weathering easily and breaking down into loose sand. But at irregular intervals vertically it shows thin layers of darker sandstone, some of which are quite compact, while others are flaggy, though they all resist the action of the weather. ***

For the greater portion, the soft yellow sandstones are devoid of fossils, but here and there Halymenites major Lesquereux occurs, and occasionally one stumbles on a little nest of Ostrea. The harder layers are quite different, many of the more compact being crowded with the Halymenites, while most of the flaggy layers contain Fox Hills fossils, among which are Ammonites lobatus, Nucula cancellata, Mactra warreniana, and numerous other species. Other layers are crowded with fragments of carbonized wood. * * * In $1873 \mathrm{Mr}$. Kelley discovered a thin layer containing impressions of dicotyledonous leaves. But the leaf specimens, with nearly all the other specimens obtained during that visit, were destroyed by an accident to the building where they were stored in Evans. During my last visit the leaf bed could not be found.

1 Stevenson, J. J., Note on the Fox Hills group of Colorado: Am. Jour. Sci., 3d ser., vol. 17, pp. 369-373, 1879.
In 1906 the University of Colorado sent out a scientific expedition to the northeastern part of the State under the direction of Prof. Junius Henderson. ${ }^{2}$ Considerable collections of fossils were obtained, and among them was a single species of plant found by Prof. Henderson near the mouth of Thompson Creek, just west of Evans. This was described in the same report by Cockerell ${ }^{3}$ under the name "Ficus sp. nov.," no specific name being given, as it was very fragmentary. It is undoubtedly the same as that here described as Rhamnus? williardi.

As nearly as can be made out the locality described by Stevenson was visited in 1910 by W. T. Lee, of the United States Geological Survey, who was especially interested in studying the relation of these beds to the Platteville coal. Mr. Lee found Fox Hills invertebrates near the top of Wildcat Mound and at several lower horizons in the massive bed of sandstone which overlies a thin bed of coal. $\mathrm{He}$ also noted the presence of dicotyledonous leaves, but did not collect specimens.

\section{THE FLORA.}

Although the known flora of the Fox Hills sandstone is still small, the importance that attaches to it makes a discussion of its affinities and relations a matter of considerable interest. The following is a list of the forms recognized:

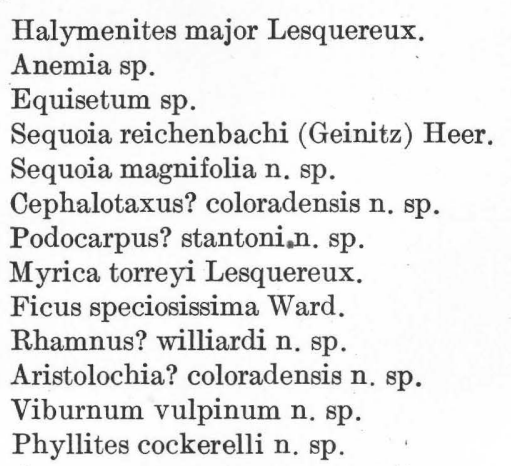

From this list it appears that only four of the named species have been previously known, the remainder being new to science or so fragmentary as not to merit specific designation. These four species are found also in the older beds of the Montana groupthat is, in the beds underlying the Fox Hills.

2 Henderson, Junius, Scientific expedition to northeastern Colorado: Colorado Univ. Studies, vol. 4, p. 151, 1907.

${ }^{3}$ Cockerell, T. D. A., A new plant (Ficus) from the Fox Hills Cretaceous: Idem, p. 152 . 
Thus Halymenites major, while most abundantly and characteristically developed in the Fox Hills sandstone, occurs also at a number of places in older beds of the Montana group, and even in still older beds of late Colorado age. It also occurs sparingly, generally in reduced size, in the Cannonball marine member of the Lance formation, which overlies the Fox Hills. Sequoia reichenbachi has a very wide range in age, extending from the Upper Jurassic to the Upper Cretaceous; it is especially abundant in the Judith River formation of the Montana group. Myrica torreyi is most abundant and widely distributed in the Montana group, but it is also found in the Laramie and rarely in postLaramie beds. Ficus speciosissima belongs to a group of closely related forms that range in age from Montana to post-Laramie, but as at present known the species occurs only in beds of the Montana group.

The form here described under the new name Sequoia magnifolia was previously known from a locality recorded as " 10 miles northeast of Greeley," which would be in the Laramie area, but there is now strong presumptive evidence that the species occurs only in the Fox Hills sandstone. The Greeley specimen has affinity with a form of Montana age. The two new species referred to Cephalotaxus and Podicarpus have no very close relationship with forms already described, though in some particulars they agree with species from the older Cretaceous. The species of Rhamnus, which is the most abundant form in the collections except the Halymenites, agrees in certain characters with Rhamnus elegans Newberry, a species supposed to come from the Laramie, but on the whole the two are very distinct. The Aristolochia is not recognized as having any very close relatives. The Viburnum belongs to a small group of species that range from the Upper Cretaceous into the lower Eocene, but it is easily separated from the others of this group. The fragment of a fern (Anemia) resembles several well-known Upper Cretaceous forms, but it is so small as to be of little value.

From the foregoing review it appears that this little Fox Hills flora shows distinctly Upper Cretaceous affinities, being, as might be presumed from its stratigraphic position, intermediate between the older floras of the Montana group and the younger flora of the overlying Laramie but having a preponderance in its resemblances to the Montana. There is very little to indicate relationship with floras of formations younger than the Laramie-that is, the Lance, Fort Union, and others-but the number of species is still far too small to be made the basis of any very extended generalization.

Ecologically this flora appears to indicate a much more abundant supply of moisture than now exists in the region, though this should naturally follow from the known fact that it must have been growing near the sea, and not far above sea level. The meager data appear to indicate a warm-temperate climate.

Descriptions of the species are given below.

\section{Halymenites major Lesquereux.}

Halymenites major Lesquereux, U. S. Geol. and Geog. Survey Terr. Ann. Rept. for 1872, pp. 373, 390, 1873; The Tertiary flora: U. S. Geol. Survey Terr. Rept., vol. 7 , p. 38 , pl. 1 , figs. $7,8,1878$.

This is undoubtedly the most abundant and characteristic plant of the Fox Hills sandstone, in which it has for many years been known to occur. It is, in fact, so uniformly present in this formation that it is almost diagnostic, though not quite, for it has been found in comparative abundance in beds as old as the Colorado and more sparsely in beds younger than the Fox Hills. It is most abundant in the Fox Hills strata, however, and perhaps grew in a greater degree of perfection during Fox Hills time. At certain localities on Cannonball River and elsewhere in North Dakota countless thousands of specimens have been noted, and it is said to be almost or perhaps quite as numerous at some places in Colorado.

\section{Anemia sp.}

Plate XV, figures 6,7 .

The collection from Wildcat Mound contains two minute fragments of a fern that with little doubt belongs to the genus Anemia. As may be seen from the enlarged figures, they probably represent only fragments of lateral divisions of a comparatively large frond. They are cut deeply into linear, sharply toothed, rather obtuse segments. The nervation is obscure. 
Occurrence: Wildcat Mound, $2 \frac{1}{2}$ miles south of Milliken, Colo.; collected by T. E. Williard.

Equisetum sp.

Plate XVIII, figure 2.

The specimen here figured is the only one in the collections that can reasonably be referred to Equisetum, and it is so small a fragment that under ordinary circumstances it would not be worthy of mention. It appears to represent the basal part of a segment of a stem pulled out of the sheath. It is about 2 centimeters in length and seems to have been nearly 1 centimeter in diameter. It is very strongly ribbed, the number of ribs, so far as can be made out, being about 12 or 14 . It is so fragmentary that any comparisons between it and described species would likely be misleading, and it is left for future exploration to establish its validity.

Occurrence: Wildcat Mound, $2 \frac{1}{2}$ miles south of Milliken, Colo.; collected by T. E. Williard.

\section{Sequoia reichenbachi (Geinitz) Heer.}

Sequoia reichenbachi (Geinitz) Heer, Flora fossilis arctica, vol. 1, p. 83, pl. 43, figs. 1d, 2b, 5a, 1868 .

This species is one of the most abundant and widely distributed forms known in this country, ranging in age from Upper Jurassic to Upper Cretaceous and in geographic distribution from the Atlantic to the Pacific. It is especially abundant and well developed in the Montana group, particularly in the Judith River formation, where it is in many places more numerous in individuals than all the other forms combined. Its presence in the Fox Hills sandstone is therefore not a matter of surprise.

Occurrence: Wildcat Mound, $2 \frac{1}{2}$ miles south of Milliken, Colo.; collected by T. E. Williard.

\section{Sequoia magnifolia n. sp.}

Plate XV, figures 1-3.

Sequoia longifolia Lesquereux, The Tertiary flora: U. S. Geol. Survey Terr. Rept., vol. 7, p. 79, pl. 7, figs. 14, 14a [not pl. 61, figs. 28, 29], 1878.

Geinitzia longifolia (Lesquereux) Knowlton, U. S. Geol, Survey Bull. 152, p. 28 [in part], 1898.

There appears to be some confusion regarding Lesquereux's Sequoia longifolia. So far as can be made out, Lesquereux had specimens of a long-leaved conifer from Black Buttes, Wyo., to which it is inferred he gave the manuscript name Sequoia longifolia. Before this name was published, however, specimens thought to represent the same form were obtained from Point of Rocks, Wyo., and the name was first published in $1876,{ }^{1}$ under the designation "Sequoia longifolia Lesq., MSS." In explanation Lesquereux adds: "This species was already described from Black Buttes specimens." I can not find that the name was ever published in connection with descriptions of the Black Buttes specimens, and it seems that when Lesquereux's description of the Black Buttes material was first published he changed the name of the long-leaved conifer noted at that place to Sequoia acuminata. ${ }^{2}$ It is certain that he nowhere definitely recorded Sequoia longifolia as coming from Black Buttes, nor has it since been found there.

If the above interpretation is correct, it establishes Point of Rocks, Wyo., as the type locality for Sequoia longifolia and excludes Black Buttes. The type specimens are the originals of figures 28 and 29 of Plate LXI of Lesquereux's "Tertiary flora" and are Nos. 73 and 74, respectively, of the United States National Museum collections. This disposition, however, leaves the specimen shown under this name in figures 14 and 14a of Plate VII of the "Tertiary flora" still to be accounted for. This specimen is said by Lesquereux to have come from the "Haley coal mine, 10 miles northeast of Greeley, Colo. (A. C. Peale);" it is No. 61 of the National Museum collections. I was informed by Dr. Peale that this statement, so far as he was concerned, is in error, for he did not obtain the specimen and in fact was never at this locality. Inasmuch as Lesquereux points out certain marked differences between the Point of Rocks and Greeley specimens and adds "It may be, therefore, that these specimens represent different species," it seems justifiable to restrict the name to the Point of Rocks specimens and such others as may be identified with them, and to consider the Greeley specimen as entitled to separate standing.

Up to the present time, however, the Greeley specimen has remained unique and the exact locality has not been identified. According to

${ }^{1}$ Lesquereux, Leo, On the Tertiary flora of the North American Lignitic: U. S. Geog. and Geol. Survey Terr. Rept. for 1874, p. 298, 1876.

2 Lesquereux, Leo, On some new species of fossil plants from the Lignitic formations: U. S. Geol. and Geog. Survey Terr. Bull., 2d ser., No. 5, p. 384 , Jan. $8,1876$. 
the geologic map of Colorado by R. D. George, published in 1913, a point 10 miles northeast of Greeley would be in an area of the Laramie formation, but now for the first time specimens that can not be distinguished from the type have been obtained in the Fox Hills sandstone about this distance southwest of Greeley. Whether there is any significance in this circumstance is impossible to say, but the species has not been recognized in the extensive recent studies of the plants of the Laramie in the Denver Basin, and it is, to say the least, uncertain as to whether the Greeley specimen came from the Laramie or the Fox Hills.

The material here described, which was obtained within about 100 feet of the top of the undoubted Fox Hills, consists of a dozen or more specimens of branches and branchlets and two or three cones. It is all more or less fragmentary, the three specimens here figured being the best. The one shown in figure 2 is indistinguishable from the original Greeley specimen. It is a branch about 8 centimeters in length and 3 millimeters in diameter. The leaves are broad, linear, rather abruptly narrowed to the base, acuminate at the apex, and 2.5 to 3 centimeters in length. The specimen shown in figure 3 is 13 centimeters long and shows the raised bases of the leaves. The cone (fig. 1) is very fragmentary, but so far as can be made out it is oblong, the long diameter being about 4.5 centimeters and the short diameter about 2.5 centimeters. Another specimen, too poorly preserved to figure, is very instructive. It is a thick leafy branch about 7 centimeters long bearing at the apex a cone that appears to be of about the same size as the one here figured.

As indicated in the synonymy, Lesquereux's Sequoia longifolia was at one time transferred to the genus Geinitzia, but the position and character of the cones above described undoubtedly preclude this reference, for they are not at all the cones of Geinitzia.

For the reasons set forth above, a new name has been given to the original Greeley specimen and the specimens from the Fox Hills sandstone identified with it.

Occurrence: About 1 mile northeast of Milliken, Colo., in the SE. $\frac{1}{4}$ NW. $\frac{1}{4}$ sec. 1 , T. 4 N., R. $67 \mathrm{~W}$.; probably within 100 feet of top of the Fox Hills sandstone; collected by T. W. Stanton, July, 1915.
Cephalotaxus? coloradensis n. sp.

Plate XV, figure 4 .

Branchlets relatively slender, strongly marked by the leaf bases; leaves apparently arranged spirally but disposed in a single plane by torsion of the petioles; leaves linear-lanceolate, rather abruptly narrowed at the base to a short petiole, narrowly acuminate at the apex; veins three, slender.

Although there are several specimens evidently belonging to this form, they are all so fragmentary that it is difficult if not impossible to formulate a satisfactory description of it. The best specimen is the one figured, and this is only a fragment of a branch or branchlet 5 or 6 centimeters long and showing not more than six leaves. The stem is rather slender for the size of the leaves, though the leaf bases are prominent. The leaves are about 4 centimeters long and about 4 millimeters broad; there seem to be three nerves or veins, though apparently the specimens show the upper side of the leaves, and possibly each leaf has a single strong midrib which, when pressed down and viewed from the upper side, makes it appear to be three-ribbed.

The generic reference is uncertain and has been questioned. The specimens appear to approach the living Cephalotaxus most closely, but it will require more and better-preserved material to settle the question with certainty.

Occurrence: About 1 mile northeast of Milliken, Colo., in the SE. $\frac{1}{4}$ NW. $\frac{1}{4}$ sec. 1, T. 4 N., R. 67 W.; collected by T. W. Stanton, July, 1915 .

Podocarpus? stantoni n. sp.

Plate XV, figure 5 .

Leaf evidently very thick and leathery in texture, narrowly lanceolate in shape, slightly narrowed below to a broad, apparently sessile base, apparently acuminate at the apex; nerves five, the middle one a little stronger than the others, slightly converging in the apical portion, outer pair smallest, running into the margin about three-fourths the length from the base; space between the nerves finely and irregularly wrinkled.

This form is represented only by the specimen figured, which is a detached leaf now 8.5 centimeters long, but it lacks the apex, which would probably make the length about 10 
centimeters when complete. The width is nearly 2 centimeters at the broadest point, not far above the base. The leaf has the appearance of having been sessile and attached by nearly half the width, but it is slightly broken at this point and it may have had a short petiole.

It is unfortunate that this form must be described from a single detached leaf, for an error in interpretation is thus easily possible. The apex and point of attachment can not be determined with absolute certainty, and this may mean much or little in its correct allocation. This leaf appears to be referable to the genus Podocarpus in its broad application, or better to the section Nageia, which is sometimes accorded separate generic rank. Thus, in general appearance this leaf strongly suggests Nageiopsis longifolia Fontaine, ${ }^{1}$ from the Potomac group of Virginia and Maryland, though the latter differs markedly in having a short, slightly twisted petiole, 9 to 12 , usually 10 nerves or veins, and noncoriaceous leaf substance. In discussing the genus Nageiopsis Berry writes as follows:

The diagnostic characters which deserve emphasis are the branching habit, the persistent leaves, and the small veins, which do not converge to any great extent in the apex of the leaf. All these serve to distinguish the species of Nageiopsis from the cycadaceous fronds or leaflets with which they are most likely to be confused.

In view of the incompleteness of the material I have decided to refer it to the genus Podocarpus with the query, and to wait until better collections are obtained before fixing its position more definitely. It is believed to be sufficiently well characterized in the above description and figure to permit subsequent recognition.

Occurrence: About 1 mile northeast of Milliken, Colo., in the SE. $\frac{1}{4}$ NW. $\frac{1}{4}$ sec. 1 , T. 4 N., R. 16 W.; collected by T. W. Stanton, July, 1915.

\section{Myrica torreyi Lesquereux.}

Plate XVII, figure 7.

Myrica torreyi Lesquereux, U. S. Geol. and Geog. Survey Terr. Ann. Rept. for 1872, p. 292, 1873; The Tertiary flora: U. S. Geol. Survey Terr. Rept., vol. 7, p. 129, pl. 16, figs. 3-10, 1878.

This species was first recorded from Black Buttes, Wyo., where it was found in beds then and long afterward regarded as of Laramie

1 Cf. Berry, E. W., Maryland Geol. Survey, Lower Cretaceous, p. 384, pl. $61,1911$. age but believed by me to be slightly younger than Laramie. Later, however, it was found that this species was fairly abundant and widely distributed in the beds of the Montana group, occurring, for instance, at Point of Rocks, Wyo., and in the Vermejo formation at Rockvale, La Veta, and Walsenburg, Colo. It is also present in the Laramie of the Denver Basin, having been found on Crow Creek about 25 miles southeast of Greeley, Colo.

The only example noted in the present collections is the fragment figured, which is a segment from the upper portion of what appears to be a normal leaf of the species.

Occurrence: Wildcat Mound, $2 \frac{1}{2}$ miles south of Milliken, Colo.; collected by T. E. Williard.

Ficus speciosissima Ward.

Plate XVI, figure 3.

Ficus speciosissima Ward, U. S. Geol. Survey Sixth Ann. Rept., p. 552, pl. 45, fig. 1, 1886; U. S. Geol. Survey Bull. 37, p. 39, pl. 21, fig. 3, 1887.

The collection contains several leaves of this form, the large one figured being not only the most perfect one but the most complete leaf in the whole collection. It is believed to be a small leaf of Ward's Ficus speciosissima, differing in being slightly broader in proportion to the length and not so deeply heart-shaped at the base. The nervation is of precisely the same type in both, except as regards the basal tertiaries.

The specimens also resemble an unnamed species of Ficus from the Vermejo formation of southern Colorado and adjacent parts of New Mexico, but the latter is still smaller and differs in a number of minor particulars. They are also very much like what Lesquereux ${ }^{2}$ called Ficus planicostata latifolia, from Black Buttes, Wyo.-in fact, they hardly differ except in size, the Wyoming leaf being considerably smaller. It thus appears that there are several forms to which different names have been given but which differ only in minor particulars, and it seems quite possible that study of a considerable number of each form, if they can be procured, will show that they should be combined into a single species. For the present, however, it seems best to keep them apart, and on account of the stratigraphic position of the leaves under consideration they are regarded as small

${ }^{2}$ Lesquereux, Leo, The Tertiary flora: U. S. Geol. Survey Terr. Rept., vol. 7 , p. 202 , pl. 31 , fig. 9,1878 . 
specimens of Ficus speciosissima, slightly broader and less distinctly heart-shaped than the type.

Occurrence: Wildcat Mound, $2 \frac{1}{2}$ miles south of Milliken, Colo.; collected by T. E. Williard and T. W. Stanton.

Rhamnus? williardi $n$. sp.

Plate XVI, figures 1, 2; Plate XVII, figures 1-4.

Ficus sp. Cockerell, Colorado Univ. Studies, vol. 4, p. 152, 1907.

Leaves very thick in texture, ovate-lanceolate, slightly unequal-sided, rather abruptly rounded below to an almost truncate base, very gradually narrowed above to an acuminate apex; margin perfectly entire; petiole very strong; nervation exceedingly strong, consisting of a thick, perfectly straight midrib, and some 15 pairs of nearly as strong secondaries, which arise at an angle of about $45^{\circ}$, curve slightly upward, and are camptodrome, each usually curving just inside the margin and joining the one next above; nervilles very numerous, strong, mainly percurrent, and approximately at right angles to the secondaries, with finer nervilles dividing the areas between the main nervilles into quadrangular areolæ. Length about 12 to 14 centimeters; maximum width, not far above the base, about 5 centimeters, though there are several leaves hardly more than 4 centimeters wide. The petiole is at least 2 centimeters long, but it is broken at this point and there is of course no means of knowing how much longer it was. On the upper side of the leaf the midrib and secondaries and even some of the nervilles are very deeply impressed, and on the under side they stand out in strong relief.

With the exception of Halymenites this species is the most abundant form in the collection, though no absolutely perfect leaf was found. The five leaves selected for illustration give, however, a very complete conception of the whole leaf.

To judge from the figure alone this species would appear to be most closely related to or perhaps even identical with Rhamnus elegans Newberry, ${ }^{1}$ from Belmont, Colo. This leaf is a little smaller and not quite so abruptly truncate at the base, but in nervation there appears to be very little difference. The type specimen of

1 Newberry, J. S., The later extinct floras of North America: U. S. Geol. Survey Mon. 35, p. 117, pl. 50, fig. 2, 1898.

$30830^{\circ}-17-7$
Rhamnus elegans, however, which is preserved in the United States National Museum (No. 10958), presents an entirely different aspect. The nervation is very thin and delicate and the nervilles are made out with much difficulty. Concerning it Newberry says:

This is a remarkably neat and symmetrical leaf, both as regards its outline and nervation. Its lines are all graceful, with little of the rigidity that characterizes the leaves of most of the Rhamnaceæ and more of the aspect of the leaf of a Jauraceous tree, but the numerous parallel side nerves, terminating all in the margins, form a character which the laurels never have.

Notwithstanding the agreement between the leaves in outline, disposition of nervation, etc., it is impossible to believe that the two could belong to the same species. They present a wholly dissimilar appearance when placed side by side.

Some years ago Prof. Junius Henderson, of the University of Colorado, collected a fragmentary leaf from the Fox Hills sandstone at the mouth of Thompson Creek, just west of Evans. This leaf was described by Cockerell ${ }^{2}$ under the name Ficus sp. nov., but on account of its fragmentary nature he did not give it a specific name. His description in part is as follows:

Leaf large, 12 centimeters in diameter, probably about 24 centimeters long, apparently very thick, with pinnate veination, and the margin nearly entire, but faintly undulate, with slightly indicated and remote teeth near the midrib. Lateral veins (secondary) few, alternate, * * * leaving the middle at an angle of about $45^{\circ}$, slightly curved, strongly curved upward toward their ends, where they become parallel with the midrib, finally branching and failing to reach the margin.

Prof. Cockerell has been kind enough to send me a photograph of this specimen, which is here reproduced (Pl. XVII, fig. 4). It shows fragments of three leaves, all evidently of the same species. So far as can be made out, little if any of the actual margin is preserved in either of the leaves, and they do not seem to agree very well with the description. These leaves appear to agree, so far as the characters can be made out, with the specimens collected by Mr. Williard, and they have been so referred.

The propriety of referring these leaves to Rhamnus may perhaps be questioned, and consequently the generic reference has been queried.

2 Cockerell, T. D. A., A new plant (Ficus) from the F.ox Hills Cretaceous: Colorado Univ. Studies, vol. 4, p. 152, 1907. 
The species has been named in honor of Mr. Thomas E. Williard, who collected the specimens figured.

Occurrence: Wildcat Mound, $2 \frac{1}{2}$ miles south of Milliken, and Thompson Creek, $1 \frac{1}{4}$ miles northeast of Milliken, Colo.; collected by T. E. Williard and T. W. Stanton.

\section{Aristolochia? coloradensis n. sp.}

Plate XVIII, figure 3.

Leaf of large size and very thick in texture, broadly ovate in general outline; deeply cordate, perhaps almost perfoliate at the base, obtuse at the apex; margin entire or very slightly undulate; nervation very strongly marked, consisting of a strong, perfectly straight midrib and about nine pairs of secondaries, the three lower pairs opposite and approximately at right angles to the midrib, the others strongly alternate, at an angle of about $45^{\circ}$ and curved upward especially above; many of the secondaries, especially in the lower part of the leaf, are forked near or above the middle and produce first a series of very large veins, then a smaller series outside; nervilles very prominent, oblique to the secondaries, mainly broken though occasionally percurrent; finer nervation not preserved. Length about 10 centimeters; width about 11 centimeters.

This large and very strongly marked species is represented only by the specimens figured. It is so curled and wrapped around that it could not be photographed and has been drawn with pen and brush as well as it could be made out. The peculiar branching of the secondaries, especially in the lower part of the blade, is well brought out in the figure. The large loops with the smaller ones outside, as well as the numerous strong nervilles, are also well shown.

There is some uncertainty about the proper generic reference of this large and well-marked leaf, hinging mainly on the interpretation of the basal configuration. If it is merely very deeply heart-shaped it may well enough belong to the genus Aristolochia, being, for instance, not greatly unlike $A$. cordifolia Newberry, ${ }^{1}$ especially in the manner of forking of the lower secondaries with the large loops outside. Aristolochia cordifolia, as its specific name im-

1 Newberry, J. S., The later extinct floras of North America: U. S. Geol. Survey Mon. 35, p. 90, pl. 60, fig. 4, 1898. plies, is deeply cordate at the base and is also markedly unequal-sided.

If, on the other hand, the base is really perfoliate it would suggest certain species of Protophyllum that form a conspicuous element in the flora of the Dakota sandstone. These species, however, are usually very different in general outline and also usually have a more or less incised margin. On the whole, it seems best to place this leaf under the genus Aristolochia with a query. Its characteristic features are so distinct that it can be readily identified if found again and thus must prove a valuable stratigraphic marker.

Occurrence: About $2 \frac{1}{2}$ miles south of Milliken, Colo., in sec. 24, T. 4 N., R. 67 W.; collected by T. W. Stanton, July, 1915.

\section{Viburnum vulpinum n. sp.}

Plate XVIII, figure 1.

Leaf very firm in texture, nearly circular in outline, slightly heart-shaped at the base, apparently obtuse and rounded at the apex; margin not preserved but presumably dentate; nervation very strongly marked, consisting of a nearly straight midrib and about five pairs of secondaries, the lower pair opposite and the others strongly alternate, the lower ones with several stong tertiary branches on the lower side, and all but the extreme upper ones with some tertiary branches; nervilles very strong, mainly unbroken and at right angles to the secondary or tertiary branches between which they run; finer nervation not retained.

This species is represented only by the example figured, which is nearly perfect except that it lacks the extreme margin. It is nearly circular in shape, being about 9 centimeters long and 8 centimeters wide. It is apparently craspedodrome and presumably ended in marginal teeth of some kind, but this feature can not be ascertained from this specimen.

This species seems undoubtedly to be congeneric with Viburnum antiquum (Newberry) Hollick, or Viburnum tilioides, as it was called by Ward, ${ }^{2}$ a species abundant and widely distributed in the Fort Union formation. The Fox Hills leaf differs from this, however, in having the fewer secondaries at a more acute

2 Ward, L. F., Synopsis of the flora of the Laramie group: U. S. Geol. Survey Sixth Ann. Rept., p. 556, pl. 61, figs. 1-7; pl. 62, figs. 1-6, 1886; Types of the Laramie flora: U. S. Geol. Survey Bull. 37, p. 107, pl. 50, figs. 1-3; pl. 51, figs. 1-8; pl. 52, figs. 1, 2, 1887. 
angle and more curved upward, but the size and entire below. Diameter 5 or 6 millimeters general appearance are much the same in both. below and 15 or 20 millimeters above. They The margins can not be compared.

Among living species both the present form and the Fort Union species appear to find their closest relationship with the European Viburnum lantana Linné and the indigenous American Viburnum lantanoides Michaux.

Occurrence: Wildcat Mound, $2 \frac{1}{2}$ miles south of Milliken, Colo.; collected by T. E. Williard.

Phyllites cockerelli n. sp.

Plate XVII, figures 5, 6.

The collection contains a number of small organisms that on casual inspection were thought to represent the sheaths of Equisetum, but more careful study discloses that they can not possibly belong to that genus. They are funnel-shaped and, so far as can be made out, are very strongly ribbed; the ribs are simple or apparently in part forked, and each rib or branch is prolonged into a long, very slender spinelike projection. The number of these spines can not be made out, though apparently there are more than 10 .

The affinity of these organisms has not been recognized. In some ways they suggest' a stipular growth, and they also resemble a persistent, spiny calyx, such, for instance, as in certain Labiateæ and Malvaceæ, but these resemblances are probably purely superficial.

The species is named in honor of Prof. T.D.A. Cockerell, of the University of Colorado.

Occurrence: Wildcat Mound, $2 \frac{1}{2}$ miles south of Milliken, Colo.; collected by T. E. Williard and T. W. Stanton. 


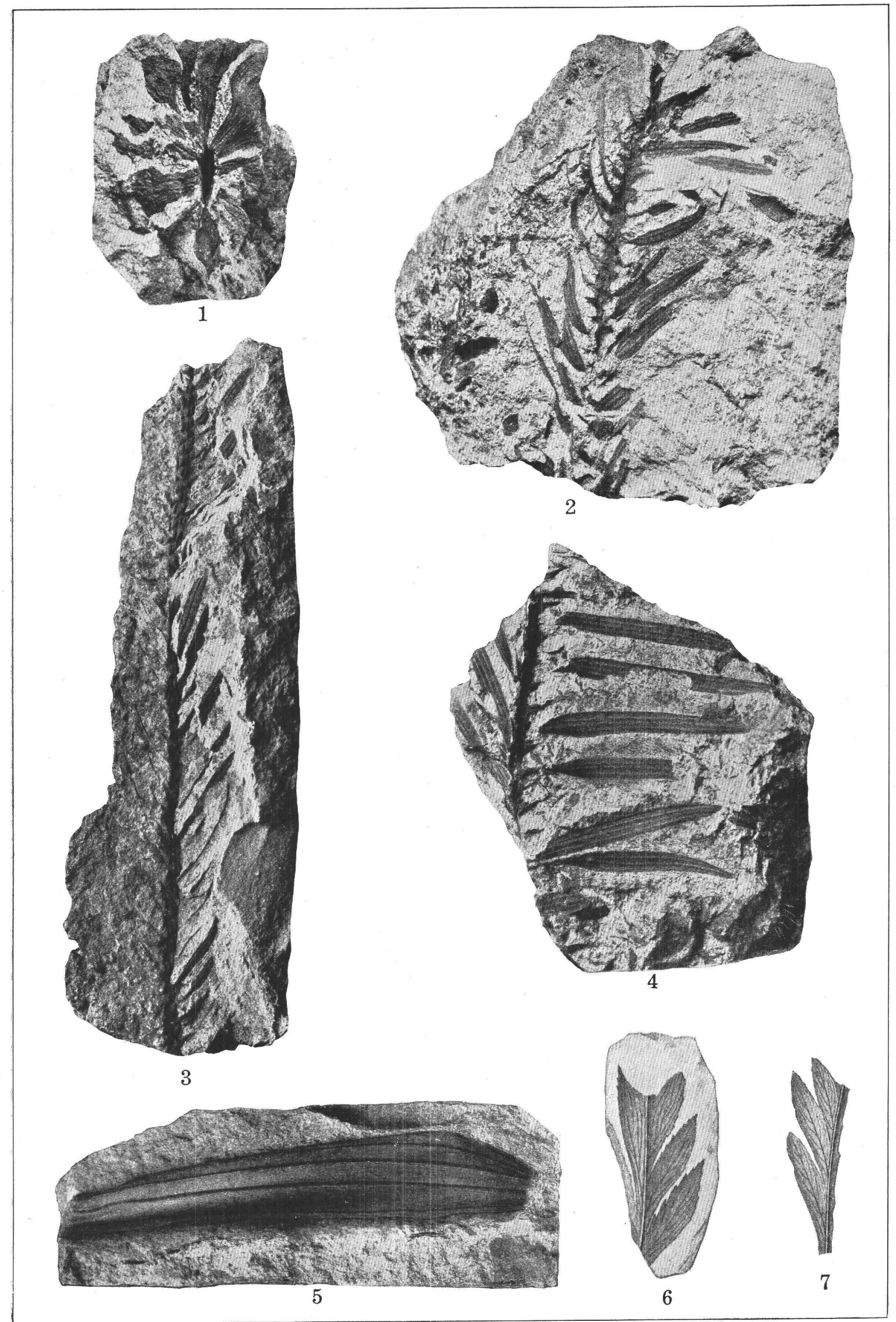

FIGURES 1-3, SEQUOIA MAGNIFOLIA N. SP; 4, CEPHALOTAXUS? COLORADENSIS N. SP.; 5, PODOCARPUS? STANTONI N. SP.; 6, 7, ANEMIA SP. $\times 3$. 


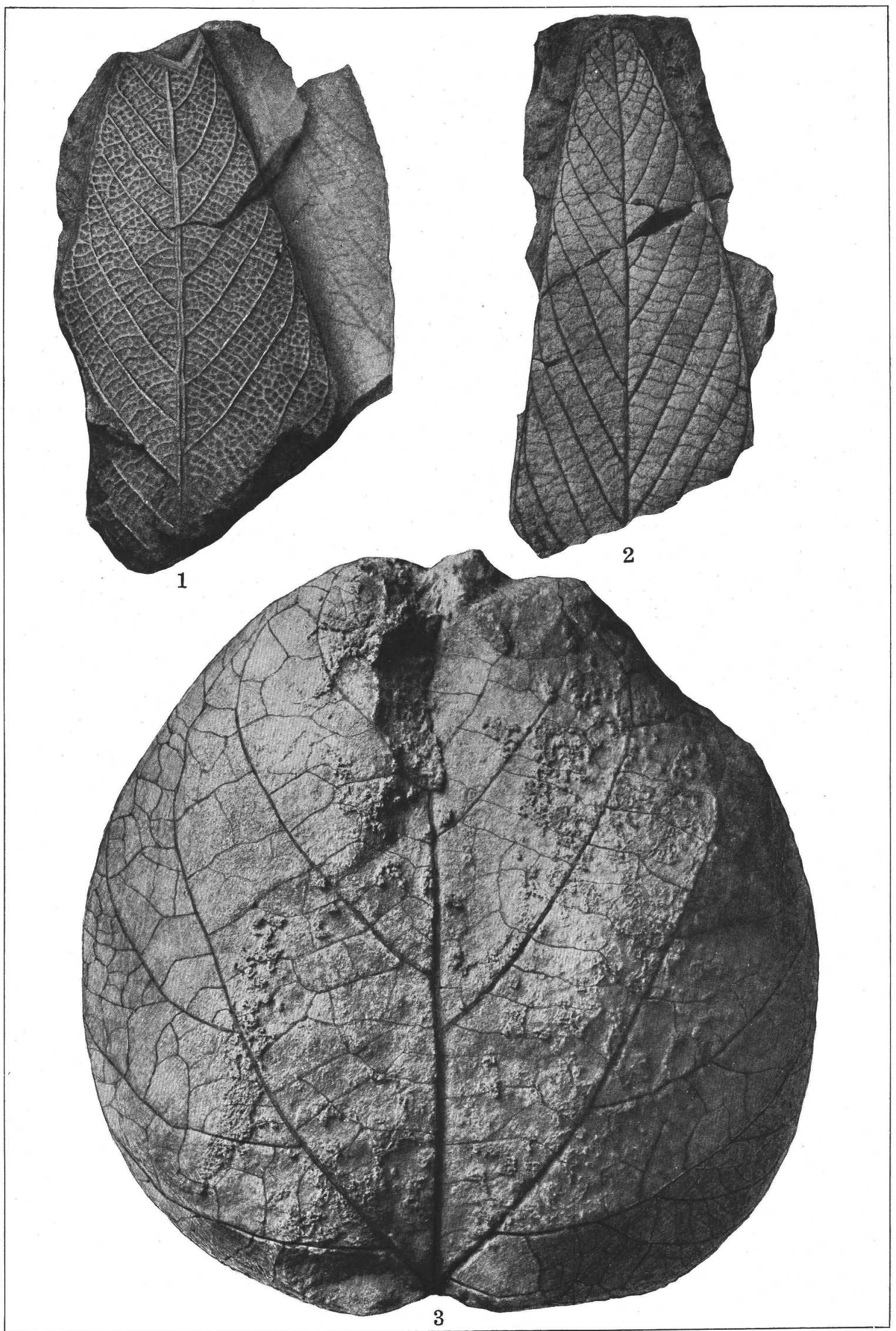

FIGURES 1, 2, RHAMNUS? WILLIARDI N. SP.; 3, FICUS SPECIOSISSIMA WARD. 


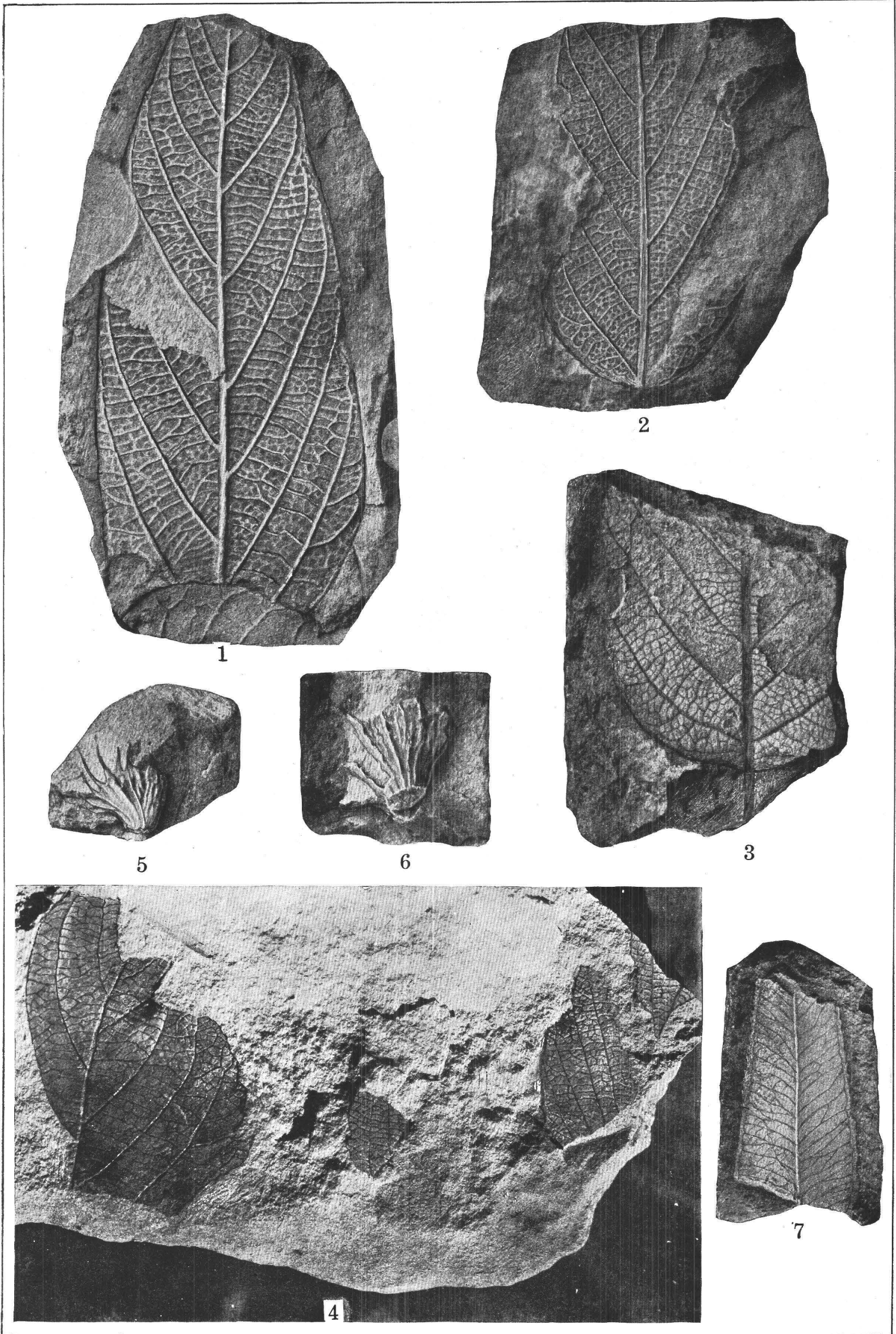

FIGURES 1-3, RHAMNUS? WILLIARDI N. SP.; 4, RHAMNUS? WILLIARDI N. SP. TYPE OF FICUS SP. COCKERELL; 5, 6, PHYLLITES COCKERELLI N. SP.; 7, MYRICA TORREYI LESQUEREUX. 


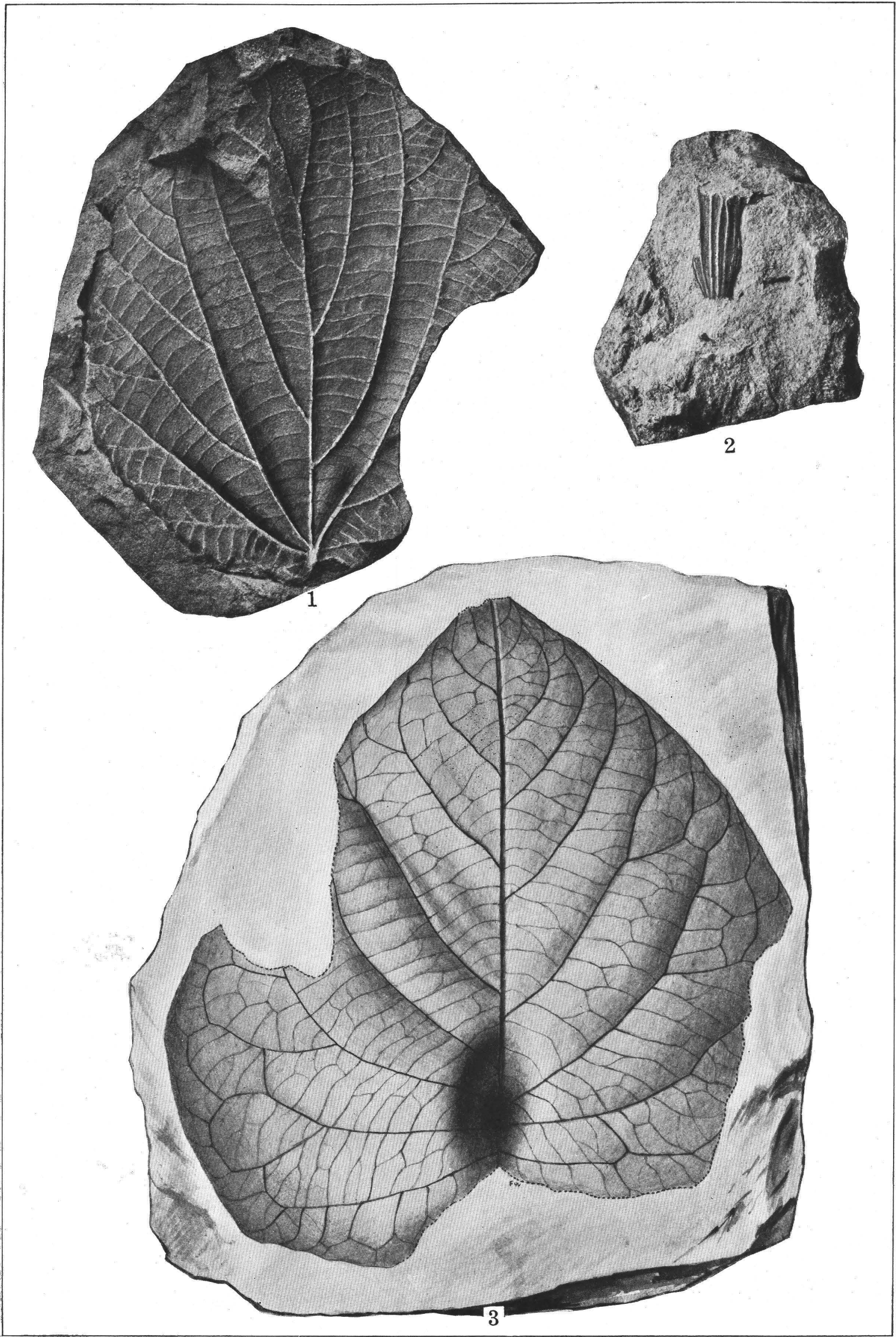

FIGURE 1, VIBURNUM VULPINUM N. SP.; 2, EQUISETUM SP.; 3, ARISTOLOCHIA? COLORADENSIS N. SP. 